常時観測データを用いた自動車交通による大気污染濃度の推計

\title{
Eștimation of air pollution from road traffic based on regular observation data
}

\section{古俣直紀 ${ }^{* *} \cdot$ 松本昌二***宮腰和弘 $* * * *$ \\ Naoki Furumata, Shoji Matsumoto and Kazuhiro Miyakoshi}

\section{1. はじめに}

地方都市では公共交通機関の未整備、施設の郊外 立地などの影響により、車交通量はますます増加す る傾向がみられ、大気污染の実態を正確に把握する ことは地域環境管理の基本である。そのために自動 車排出ガス測定局（以下、自排局とする）が設置さ れ、連続的に污染濃度の監視を行っており、その設 置場所は近くに住居があり、交通量が多く渋滞して いる路線の道路端、交差点近傍となっている。

しかし、新潟市周辺に設置されている自排局は 5 ヶ所にすぎない。1992年度現在の $\mathrm{N}_{2}$ 濃度を測定し ている全国の自排局は 345 所であり、一般局の数 1,406に較べて極めて少ない。 ${ }^{1}$ 渋滞地点全てに自 排局を配置することはコスト的に困難であるとはい え、商業施設の新設、道路の整備等による渋滞地点 の位置変化に対応しきれていないと言えよう。

一方、車交通量、渋滞状況などについては、警察 署と建設省によって常時観測されている箇所が市街 地に多く分布している。これら常時観測データを利 用して、多数の渋滞地点の污染濃度を推計し監視す ることは、環境管理の補完的な方法になり得ると考 える。

そこで本研究は、新潟市を対象として、交通、気 象などの常時観測されているデータのみを用いて、 自動車交通による沿道の大気污染濃度を推計する方 法について実用性を検討することを目的としており、 その実用性の範囲内で渋滞地点の濃度推計を試みて いる。

\footnotetext{
*キーワート・計画情報、交通公害

**正会員工修 日本道路公団

（テ100 東京都千代田区霞が閔33-2 TEL:03-3506-0111）

***正会員 工博 長岡技術科学大学工学部教授 環境 - 建設系

(干940-21 長岡市上富岡町 1603-1 TEL:0258-46-6000)

****正会員 工博 長岡工業高等専門学校鱑境都市工学科

（干940 長岡市西片貝町 888 TEL:0258-34-9280)
}

詳細な車交通流の実態にもとづいた大気污染予測 モデルに関しては、かなり研究が蓄積されている ${ }^{2) 。}$ 本研究では、常時観測データを用いるという制約か ら、我が国の道路の環境影響評価で実用化されてい る濃度推計の方法を採用した。

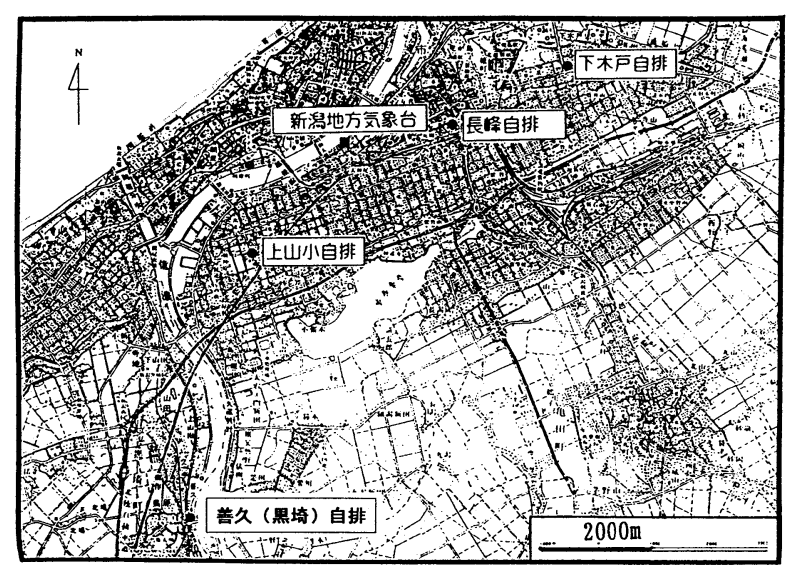

図-1 対象自排局の位置

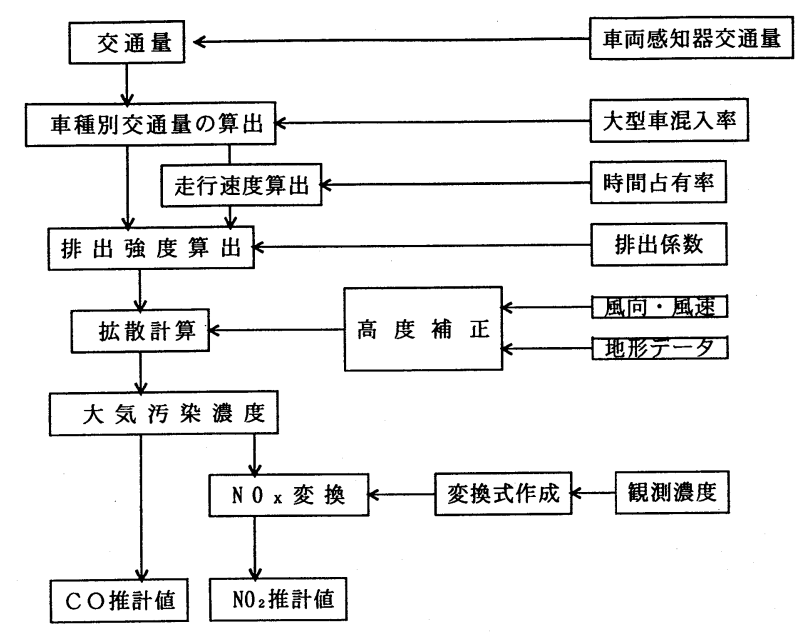

図 -2 濃度推計フロー 


\section{2. 推計の方法}

大気污染物質の中から、自動車交通の影響を考慮 して、窒素酸化物と一酸化炭素を推計対象とした。 対象とした自排局は、新潟市設置の 3 ケ所（上山小、 下木戸、長峰）と新潟市周辺で県設置の 1 ヶ所（黒 埼）であり、図ー 1 にその位置を示す。これら 4 ケ 所の測定場所は、道路端から 3.3-9.3m離れ、地上高 3. 0-4. 2mにある。

濃度推計方法は、「建設省所管道路事業環境影響 評価技術指針」3）4）をベースとした排出強度の算出、 拡散計算によるものであり、図ー 2 にフローを示す。 本研究では、常時観測データのみを用いるため、以 下の条件を設定した。

(1)自動車走行台数については、平成 2 年道路交通 情勢調查（以下、道路センサスとする）の交通 量、および車両感知器 (以下、ディテクターと する）観測の交通量を用いる。

(2)大型車の走行台数は、道路センサスによる24時 間観測の大型車混入率を用いて算出する。

(3)走行速度は、ディテクターによって観測された 時間オキュパンシーに基づいて算出する。

(4)新潟市内の観測值からあらかじめ $\mathrm{N} 0 x$ 変換式

を作成し、推計された $\mathrm{N}_{\mathrm{x}}$ 濃度を $\mathrm{N}_{2}$ 濃度に変換 して、環境基準と比較する。

\section{3. 推計の前提条件}

\section{1) ディテクター交通量}

ディテクター観測の交通量について、新潟市内 4 地点で道路センサス交通量との比較を行った。図ー 3 は、上山小自排局の近傍道路において、ディテク ター交通量と道路センサス交通量とを比較したもの である。両者の時間交通量の寄与率は 0.991 が得ら れ、ディテクター交通量は十分な信頼性があると認 められた。

\section{2 ) 大型車混入率}

平成 2 年道路センサス ${ }^{5)}$ をもとに、新潟市内市街 地部および郊外部の大型車混入率を設定した。24時 間観測点の中から、市街地部については万代 2 丁目 と内野、郊外部については一日市と鳥屋野を選び、 それぞれの平均値を大型車混入率とした。図ー4は、 本推計において設定した平日の大型車混入率である。 3 ）走行速度
走行速度については、ディテクター観測の時間占 有率より以下の式(1)を用いて算出した。なお、平 均車長（L）については、大型車の混入を考慮し、 大型車混入率によって加重平均を行った。この方法 はかなり誤差を伴うものであるけれども、やむを得 ず採用した。

$$
\mathrm{V}=\frac{\mathrm{Q}}{\mathrm{Occ}} \times(\mathrm{L}+\mathrm{d}) \cdots \cdot(1)
$$

ただし、 $\mathrm{V}:$ 走行速度 $(\mathrm{Km} / \mathrm{h}) 、 \mathrm{Q}:$ 走行台数 (台 $/ \mathrm{h}) 、 \mathrm{~L}:$ 平均車長 $(\mathrm{m}) 、$ $\mathrm{O} c \mathrm{c}$ : 時間占有率、 $\mathrm{d}:$ 感知領域 (m)

4) 排出係数

排出係数については、建設省土木研究所および東 京都環境保全局の行った 2 種類の調査結果を比較検 討した。 ${ }^{6 ）}{ }^{7)} 2$ 種類の排出係数を走行速度全域にわ たって設定するため、2 次式または 3 次式の回帰分

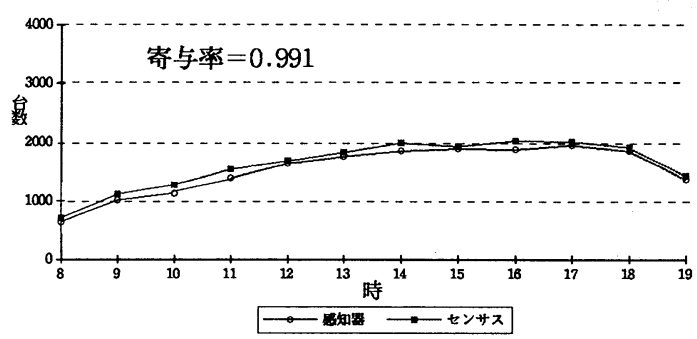

図 -3 上山小観測交通の比較

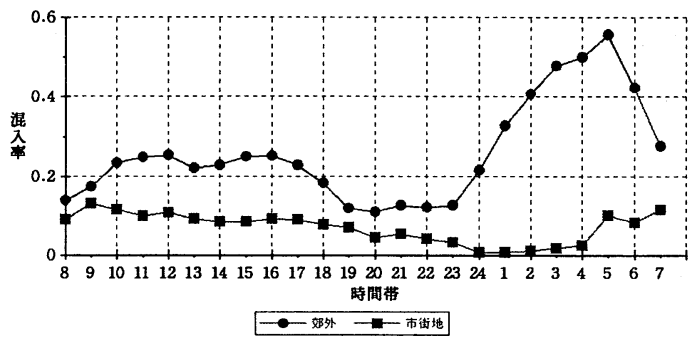

図 -4 新潟市内大型車混入率（平日）

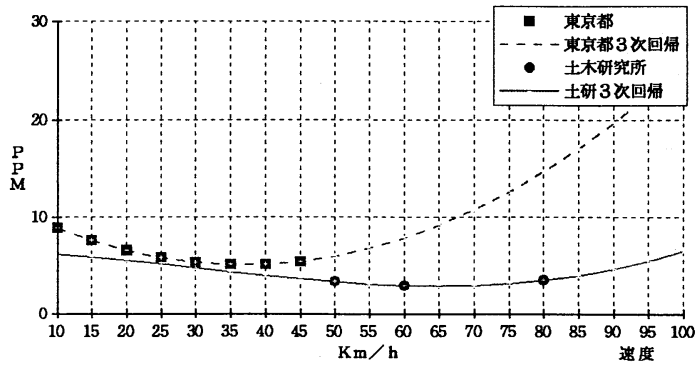

図－5 N0x排出係数（大型車） 
析により補間を行った。その排出係数を用いて、上 山小、下木戸地点の 12 時間污染濃度を推計して自排 局観測值と比較したところ、土木研究所の方が相関 が高いため、その回帰式を用いることとした。図ー 5 に本研究の排出係数の一例（N0x大型車）を示す。 5 ）風向・風速

風向・風速については、新潟地方気象台観測によ る16方位時間別データを用いた。また、風速につい ては、式（2）によって、予測点高度での風速を算出 した。

$$
\mathrm{U}=\mathrm{U}_{0}\left(\mathrm{H} / \mathrm{H}_{0}\right)^{\alpha} \cdots \cdot(2)
$$

ただし、U：高さ $H(m)$ の推計風速 $(\mathrm{m} / \mathrm{s})$

$\mathrm{U} 0:$ 基準高さ $\mathrm{H} 0(\mathrm{~m})$ の風速 $(\mathrm{m} / \mathrm{s})$

$\alpha:$ べき指数 [市街地 $: 1 / 3$ 、郊外 : 1/5]

拡散式については、「建設省所管道路事業環境影 響評価指針」 ${ }^{4)}$ に従い、有風時（風速が $1 \mathrm{~m} / \mathrm{s}$ を超え る場合）にPlume式、静穏時（風速が $1 \mathrm{~m} / \mathrm{s}$ 以下の場

合）にPuff式を使用している。

6 ) N0x変換式

環境基準で定められる $\mathrm{N}_{2}$ 濃度を推定するために、 新潟市における $\mathrm{N} 0 \mathrm{x}$ 変換式を作成した。平成 4 年度 の一般局国設新潟の $\mathrm{N} 0 \mathrm{x} 、 \mathrm{~N}_{2}$ 濃度時間平均值につい て回帰分析を行い、変換式 (3) が寄与率0.922で得ら れた（図-6）。采ここれ建設省土木研究所の式 （土研式）に比べて $2-3$ 倍高い值となる。10)

$$
\mathrm{N}_{2}=0.418 \cdot \mathrm{NO}_{\mathrm{x}}+0.0018 \quad \cdots \cdot(3)
$$

\section{4. 大気污染の現況と推計結果}

1) 対象地点の交通状況

上山小地点の交通状況（平日）を図ー7に示す。 自排局 4 ヶ所のほとんどで、昼間の時間交通量は 2,000台を超えている。大型車走行台数は、本研究 において設定した大型車混入率によって算出した台 数であるが、朝ピークの時間帯に多くなっている。 路線バスの走行を考慮した場合、実際の走行状況を うまく再現できていると考える。また、梁夜の走行 速度は高いのが通常であるが、図ー 7 では特に高く 推定されている。これは時間占有率の有効数字の少 ないことが主な原因であり、高速時ほど（時間占有 率が小さいほど）誤差が大きくなる性質を持ってい る。従って媣夜の走行速度については、信頼性に欠
けると推察される。

2 ) 対象地点における観測濃度 ${ }^{8)}$

NOx、COについて、月平均観測濃度の経年変化を みると、どの自排局でも極端な高濃度は観測されて いない（上山小の月平均濃度の N0xは0. 02-0. 05ppm、 COは0. 4-0. 6ppm）。また、冬季になると観測濃度が

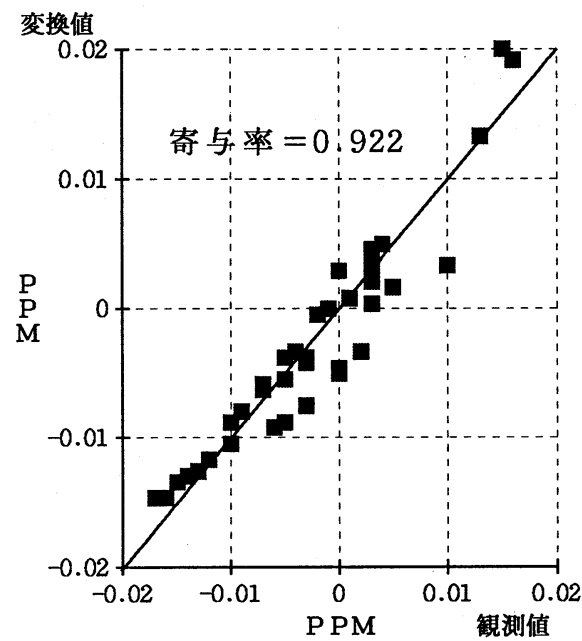

図-6 $\quad \mathrm{N} 0 \mathrm{x}$ 変換式の相関図

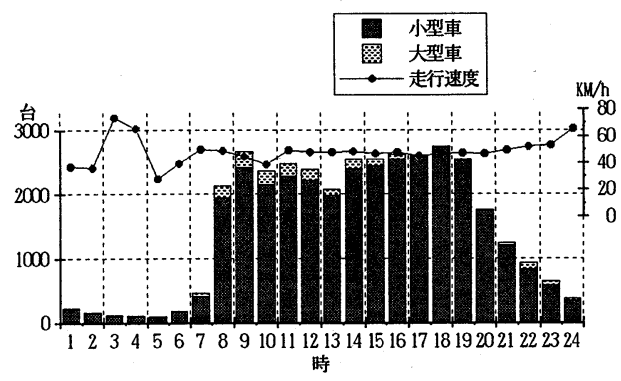

図-7 上山小の交通状況（平日）

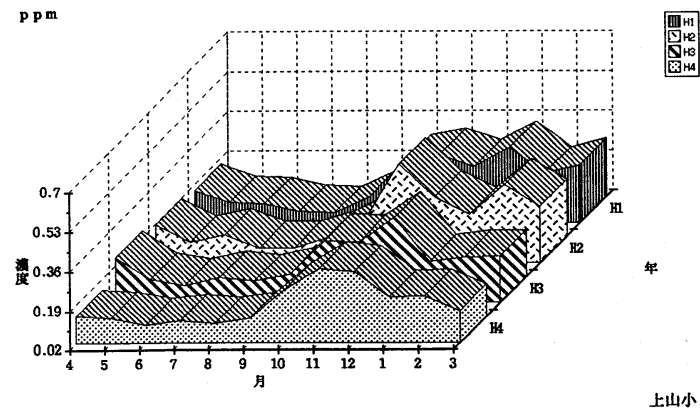

図-8 N0x月ピ -ク濃度経年変化（上山小、平日） 
高くなり、一般的に言われているN0x濃度が冬季に 高くなるという傾向が、新潟市においても確認され た。この傾向は、自動車排出ガスの直接的影響が比 較的少ない一般局でも同様にみられた。

また、月間ピーク濃度は、図ー8、図ー9のよう に、月平均濃度のおよそ 10 倍前後の值が観測され ており、新潟市のような地方都市においても、ピー ク時にはかなり高い濃度になることがわかる。

\section{3 ) 時間帯別濃度の推計}

N0x とC0の污染濃度は、前述のように秋から冬に かけて高いので、冬季の高濃度期について污染濃度 の推計を行った（平日は1994年11月15日、休日は19 94 年11月 30 日）。自排局 4 ヶ所のなかで推計精度が 最も高かった上山小地点について、濃度推計の結果

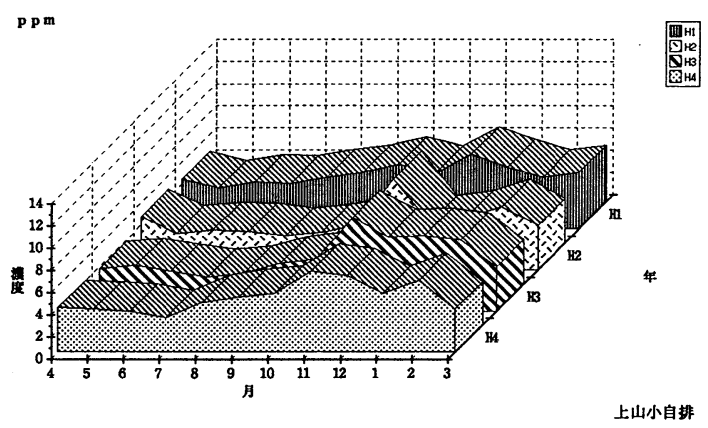

図－9 CO月ピ - 濃度経年変化（上山小、平日）

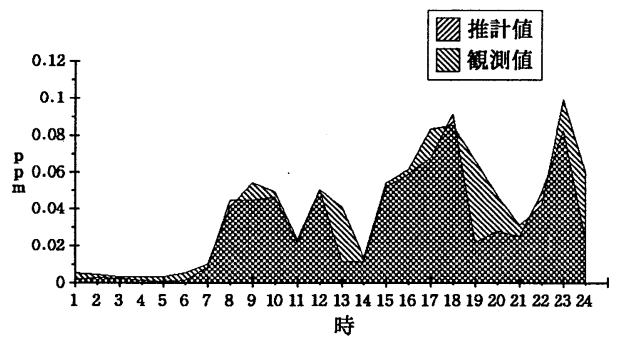

図一 $10 \mathrm{~N} 0 \mathrm{x}$ 推計濃度（上山小、平日）

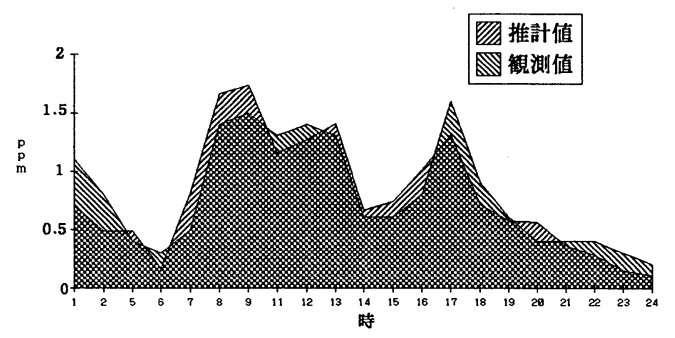

図-11 C0推計濃度（上山小、平日）
を図ー10、11に示す。なお、バックグラウンド濃度 は時間変動が大きく、推計值に加算する場合としな い場合を比較したところ、統計的には加算しない場 合の方が適合度が高いので、加算しないこととした。

表一 1 は、対象 4 地点における時間帯別濃度の推 計值と観測值の R M S 誤差と寄与率を示したもので ある。N0x濃度の推計については、長峰地点の推計 においてRMS誤差が大きかった。これは、周辺に建 造物があり、風向・風速データが設定した值と異な るためと考える。CO濃度の推計については、全体的 にRMS誤差が大きく、これは排出係数の設定に問題

\begin{tabular}{|c|c|c|c|c|}
\hline \multicolumn{2}{|c|}{ 表一 1} & \multicolumn{2}{|c|}{ 対象 4 地点の時間帯別 } & 農度推計結果 \\
\hline \multirow[b]{2}{*}{ 窒 } & & 地 区 & R M S 誤差 & 寄与率 $\left(\mathrm{R}^{2}\right)$ \\
\hline & \multirow[t]{3}{*}{ 平 } & 上山小 & 0.0148 & 0.799 \\
\hline 素 & & 下木戸 & 0.0723 & 0.684 \\
\hline \multirow{2}{*}{$\begin{array}{l}\text { 酸 } \\
\text { 化 }\end{array}$} & & 長峰 & 0.2171 & 0.612 \\
\hline & 日 & 黒埼 & 0.0349 & 0.814 \\
\hline \multirow{4}{*}{$\begin{array}{l}\text { 物 } \\
\text { 推 } \\
\text { 計 }\end{array}$} & \multirow[t]{3}{*}{ 休 } & 上山 小 & 0.0122 & 0.788 \\
\hline & & 下木戸 & 0.0660 & 0.550 \\
\hline & & 長 峰 & 0.0575 & 0.550 \\
\hline & 旦 & 黑埼 & 0.0783 & 0.188 \\
\hline \multirow{2}{*}{ 一 } & \multirow[t]{3}{*}{ 平 } & 上山 小 & 0.1841 & 0.830 \\
\hline & & 下木戸 & 1. 1462 & 0.088 \\
\hline \multirow{2}{*}{$\begin{array}{l}\text { 化 } \\
\text { 炭 }\end{array}$} & & 長 峰 & 0.9761 & 0.581 \\
\hline & 日 & 黒 埼 & 0.4223 & 0.588 \\
\hline \multirow{4}{*}{$\begin{array}{l}\text { 素 } \\
\text { 推 } \\
\text { 計 }\end{array}$} & \multirow[t]{3}{*}{ 休 } & 上山小 & 0.2252 & 0.625 \\
\hline & & 下木戸 & 1. 0985 & 0.086 \\
\hline & & 長 峰 & 1.0426 & 0.023 \\
\hline & 日 & 黒埼 & 0.9126 & 0.192 \\
\hline
\end{tabular}

（網掛け部分は、 $\mathrm{R}^{2} 0.55$ 以上、RMS 0.2 以下）

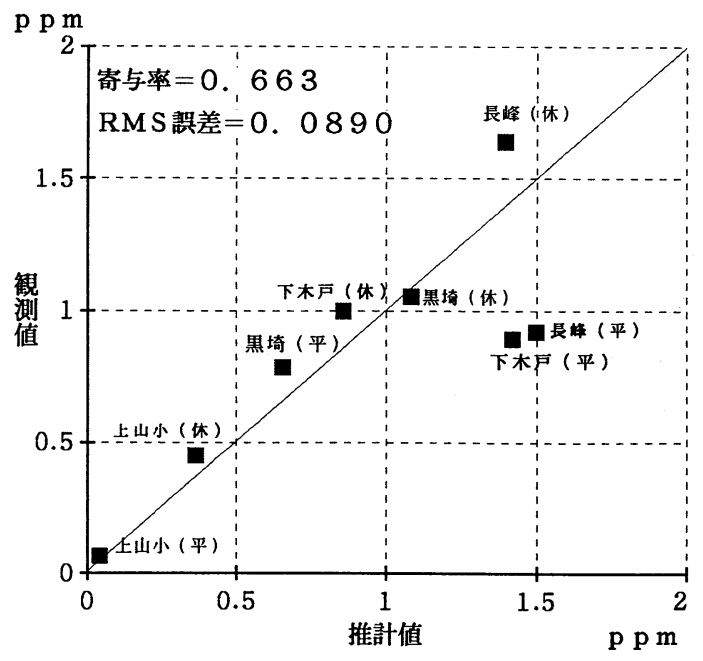

図-12 日平均 $0 x$ 濃度相関図 
があったと考える。特に、下木戸地点のCOについて は、交差点を 2 本の単路部とみなして推計したため に大きな誤差が生じたと考える。寄与率は、全体的 に平日に比べて休日に低い值となり、これは休日の 大型車混入率の設定に問題があると考える。

\section{4) 日平均濃度の推計}

環境基準が日平均で定められていることから、時 間帯別に求めた大気污染濃度を平均して日平均の濃 度を求めた。図ー12、図ー13は，それぞれN0x、C0の 日平均濃度を示したものである。この結果でも長峰 地点、下木戸地点は推計の適合度が低いが、長峰地 点は風向・風速データに問題があり、下木戸地点は 交差点部であることが影響していると考える。

\section{5 ) 推計方法の実用性}

常時観測データのみを用いた時間帯別濃度の推計 方法は、N0x濃度ではおおむね $\mathrm{R}^{2}=0.55-0.8$ 得ら れ、実用性があると評価できる。CO濃度では、半分 の地点で $\mathrm{R}^{2}=0.2$ 以下であるため、実用性は低い。 しかし、日平均濃度に関しては、Nox、C0共に $\mathrm{R}^{2}=$

0.7 近い值が得られ, 全体の傾向を知るためには 実用的な方法と言える。

本研究の濃度推計フローでは、排出強度の算定と 拡散計算の二段階から誤差が生じる。第一段階では 土木研究所の排出係数と大型車混入率が、第二段階 では風向風速データが、誤差の主な原因である。

\section{5. 啮滞地点における濃度推計}

新潟市周辺の平成 5 年渋滞実態調査 ${ }^{9)}$ により、朝 タピーク時に $1,000 \mathrm{~m}$ 程度の渋滞が認められた箇所の 中から 6 地点を選び、道路端 $2 \mathrm{~m}$ 、地上高 $1.5 \mathrm{~m}$ の 場所で、実用性があると判定された $0 x 、 \mathrm{~N}_{2}$ 濃度を 推計した（表一 2 ）。時間は、平成 2 年 10 月 2 日、 午前 7 時から 8 時、午後 4 時から 5 時の 2 つの時間 帯とした。時間交通量は、2,000から3,000台の個所

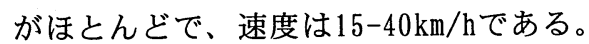

比較のために、表ー 3 に自排局のピーク時観測濃 度を示す。表一 2 の推定値と表ー 3 の観測値が著し く違う主な原因は、自排局の測定場所が道路端・地 上高とも離れているからと考えられる。

環境基準は、時間濃度の 1 日平均值で設定されて おり、 $\mathrm{N} 0_{2}$ が $0.06 \mathrm{ppm}$ となっている。本研究の変換式 (3)によれば、N0xで0. 169ppmである。今回の渋滞地
点における推計結果は時間推計值ではあるが、 $\mathrm{N}_{2}$ 濃度は環境基準を越えて非常に高く、自排局におけ るピ-ク時の10倍以上の值が推計された。自排局の測 定場所が、道路近傍の污染濃度の高い所に必ずしも 位置していないことに注意が必要である。

\section{6. まとめ}

交通、気象などの常時観測データのみを用いて、 $\mathrm{NO}_{2}$ とC0の大気污染濃度を推計する方法について、 実用性とその問題点が明らかになった。時間濃度の 推計方法は、N0x濃度では実用性があると評価でき

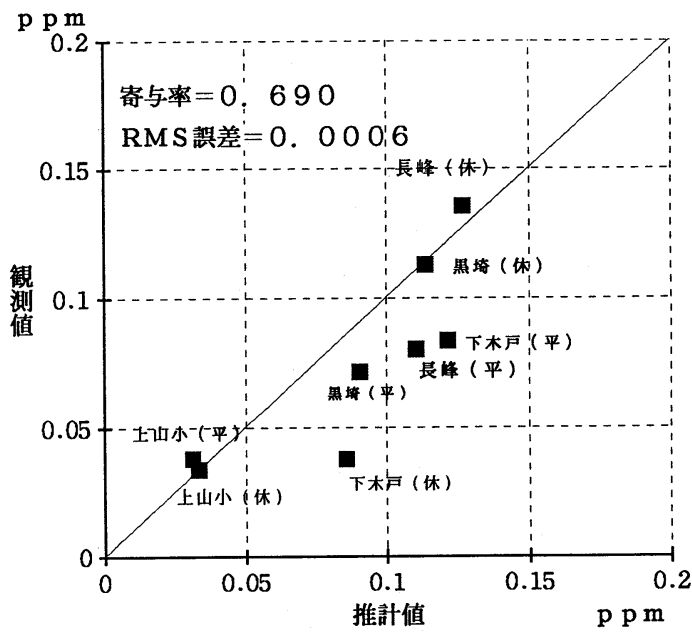

図-13 日平均 $\mathrm{C} 0$ 濃度相関図 表 -2 渋滞地点のピーク時濃度推計結果

\begin{tabular}{|c|c|c|c|c|c|c|}
\hline 地 区 & $\begin{array}{l}\text { 時 } \\
\text { 間 }\end{array}$ & $\begin{array}{c}\text { 小型車 } \\
\text { (台) }\end{array}$ & $\begin{array}{c}\text { 大型車 } \\
\text { (台) }\end{array}$ & $\begin{array}{l}\text { 速度 } \\
\mathrm{Km} / \mathrm{h}\end{array}$ & $\mathrm{NO}_{x}$ & $\mathrm{NO}_{2}$ \\
\hline \multirow[t]{2}{*}{ 明石 1 丁目 } & 朝 & 2811 & 258 & 18.4 & 0.9356 & 0.3799 \\
\hline & 夕 & 3429 & 149 & 14.8 & 0.3162 & 0.1213 \\
\hline \multirow[t]{2}{*}{ 笹越橋 } & 朝 & 2320 & 212 & 40.2 & 0.5067 & 0.2234 \\
\hline & 夕 & 2044 & 89 & 26.5 & 0.1903 & 0.0687 \\
\hline \multirow[t]{2}{*}{ 大野大橋西詰 } & 朝 & 2847 & 262 & 24.8 & 0.7287 & 0.2935 \\
\hline & 夕 & 2552 & 111 & 26.8 & 0.2483 & 0.0929 \\
\hline \multirow[t]{2}{*}{ 黒埼 I C } & 朝 & 1394 & 128 & 28.3 & 0.3731 & 0.145 \\
\hline & 夕 & 2271 & 99 & 43.7 & 0.3261 & 0.1254 \\
\hline \multirow[t]{2}{*}{ 小針 I C } & 朝 & 2037 & 187 & 14.3 & 0.4888 & 0.1933 \\
\hline & 夕 & 2370 & 103 & 49.8 & 0.2689 & 0.1015 \\
\hline \multirow[t]{2}{*}{ 有明大橋東詰 } & 朝 & 1495 & 137 & 18.2 & 0.7284 & 0.2934 \\
\hline & 夕 & 2292 & 99 & 10.7 & 0.2668 & 0.1007 \\
\hline
\end{tabular}

表 -3 自排局の朝夕ピーク時観測濃度

\begin{tabular}{|l|l|c|c|c|c|}
\hline 地 区 & $\begin{array}{c}\text { 時 } \\
\text { 間 }\end{array}$ & $\begin{array}{c}\text { 小型車 } \\
\text { (台) }\end{array}$ & $\begin{array}{c}\text { 大型車 } \\
\text { (台) }\end{array}$ & $\mathrm{NO}_{\mathrm{x}}$ & $\mathrm{NO}_{2}$ \\
\hline \multirow{2}{*}{ 上山小 } & 朝 & 2582 & 273 & 0.084 & 0.026 \\
\cline { 2 - 6 } & $夕$ & 2527 & 238 & 0.054 & 0.013 \\
\hline \multirow{2}{*}{ 下木戸 } & 朝 & 1883 & 170 & 0.074 & 0.022 \\
\cline { 2 - 6 } & 夕 & 1808 & 129 & 0.131 & 0.047 \\
\hline
\end{tabular}

上山小: 道路端 $9.3 \mathrm{~m}$ 、地上高 $4.2 \mathrm{~m}$

下木戸："3.3m、" $4.0 \mathrm{~m}$ 
るが、C0濃度では実用性は低い。しかし、日平均濃 度に関しては、N0x、CO共に全体の傾向を知るため には実用的な方法と言える。

本研究の濃度推計フローでは、排出強度の算定と 拡散計算の 2 段階から誤差が生じる。第 1 段階では、 土木研究所や東京都以外の排出係数の適用、および 大型車混入率の推定や実測の問題を考慮する必要が ある。第 2 段階では、推定する地点近傍の風向風速 データを実測または推定によって確保することが望 ましい。

\section{【参考文献】}

1 ) 柴田徳衛、他: 車依存社会、自動車排ガス污染 から考える、実教出版、1995.

2) A. Matzoros and D. V. Vliet:A model of air pollution from road traffic, based on the characteristics of integrated flow and junction control: PartII-Model results, Transportation Research 26A, 4, 331-355, 1992. 有薗 卓、他：交通制御による大気污染低減効
果の評価用実用型シミュレータに関する研究、 環境保全研究成果集、環境庁、1991.

3）日本道路協会：道路環境整備マニュアル、 1989.

4 ）金安公造：道路の環境、交通工学実務双書、 第 10 巻、 1988 .

5 ）建設省北陸地方建設局：全国道路交通情勢調 查、 1991 .

6 ）足立義雄、他：道路走行時における自動車排 ガス量に関する研究、土木研究所報告、第 164 号、 1984.

7 ) 東京都環境保全局：都市内自動車交通量およ び自動車排出ガス量算出調查報告書、1992.

8 ）新潟県環境保健部公害対策課：大気污染測定 結果報告、1993.

9）建設省北陸地方建設局新潟国道工事事務所： 渋滞実態調査作業報告書、1993.

10）島津康男：新版環境アセスメント、NHKブック ス、 1987.

常時観測データを用いた自動車交通による大気污染濃度の推計

古俣直紀・松本昌二・宮腰和弘

新潟市内の自動車排出ガス測定局 4 ヶ所を対象として、交通、気象の常時観測されているデータのみ を用いて、自動車交通による沿道の大気污染濃度（窒素酸化物と一酸化炭素）を推計し、その誤差を 検定することによって、常時観測データのみによる濃度推計の実用性を検討する。濃度推計方法は、 「建設省所管道路事業環境影響評価技術指針」をベースにする。その結果、常時観測データのみを用 いる推計方法は、N0x時間濃度では実用性があると評価できるが、CO時間濃度では実用性が低い。日 平均濃度に関しては、NOx、CO共に全体の傾向を知るためには実用的な方法と言える。問題点として、 採用する排出係数、大型車混入率の推定や実測、風向風速デー夕の実測または推定があげられる。

Estimation of air pollution from road traffic based on regular observation data

Naoki Furumata, Shoji Matsumoto and Kazuaki Miyakoshi

This paper develops the method to estimate air pollution concentrations from road traffic by using regular observation data of traffic and wind, and idetifies its applicability. The analysis uses the observation data of air pollution (nitrogen oxide and carbon monoxide) at the four measuring stations in the city of Nigata, and applies the method of estimating air pollution for the Environmental Impact Assessment of highways. The result reveals the possibility of using regular obserbation data, but some analytical problems such as the estimation errors of vehicle emission rates, traffic of large vehicles, and the direction and velocity of wind. 